University for Business and Technology in Kosovo

UBT Knowledge Center

UBT International Conference

2012 UBT International Conference

Nov 2nd, 9:00 AM - Nov 3rd, 5:00 PM

\title{
Urban waste water discharges and their treatment: Case study Waste Water Treatment Plant of Kavaja (WWTPK)
}

Aida Bode

Polytechnic University of Tirana, boaal@yahoo.com

Nevton Kodhelaj

Polytechnic University of Tirana, nevtonkodheli@yahoo.com

Piro Zoga

Polytechnic University of Tirana, pzoga@yahoo.com

Doriana Xhulaj

Agricultural University of Tirana, b_dori23@yahoo.com

Follow this and additional works at: https://knowledgecenter.ubt-uni.net/conference

Part of the Computer Sciences Commons, and the Engineering Commons

\section{Recommended Citation}

Bode, Aida; Kodhelaj, Nevton; Zoga, Piro; and Xhulaj, Doriana, "Urban waste water discharges and their treatment: Case study Waste Water Treatment Plant of Kavaja (WWTPK)" (2012). UBT International Conference. 70.

https://knowledgecenter.ubt-uni.net/conference/2012/all-events/70

This Event is brought to you for free and open access by the Publication and Journals at UBT Knowledge Center. It has been accepted for inclusion in UBT International Conference by an authorized administrator of UBT Knowledge Center. For more information, please contact knowledge.center@ubt-uni.net. 


\title{
Urban waste water discharges and their treatment: Case study Waste Water Treatment Plant of Kavaja (WWTPK)
}

\author{
Aida Bode $^{1}$, Nevton Kodhelaj ${ }^{2}$, Piro Zoga ${ }^{1}$, and Doriana Xhulaj ${ }^{3}$, \\ ${ }^{1}$ Faculty of Geology and Mining (Mineral Resources Engineering Department), Polytechnic University of Tirana, \\ Albania \\ Email: aida.bode@fgjm.edu.al; boaal@yahoo.com;pzoga@albmail.com \\ ${ }^{2}$ Faculty of Geology and Mining (Energy Resources Department), Polytechnic University of Tirana,Albania \\ Email: nevtonkodheli@yahoo.com \\ ${ }^{3}$ Genetic Resource Center, Agricultural University of Tirana,Albania \\ Email:b dori23@yahoo.com
}

\begin{abstract}
WWTPK is the first plant built sewage purification in the Republic of Albania (RA). This plant it is placed in the Kavaja region, district of Tirana. For this is an important area sewage treatment and waste water treatment according to the standards of the Ministry of Environment, Forestry and Water Management (MoE) in Republic of Albania and not directly discharged untreated in nature.

In order to determine productivity of the IPUZ and to predict the future of the operation, the results of the analysis of BOD, COD, SS are produced. According to chemical analyzes carried out in the period from February to May-June 2012 the water quality of effluents meet the standards under MoE for BOD, SS and COD parameters. The method used in this plant is the two stage method, physical and biological treatment. It is important to mention the lack of measurement of $\mathrm{pH}$, temperature and $\mathrm{O} 2$ for a period of more than 1 year; and the lack of measurement of total phosphorus as a procedure, as a determinant of nutrients eutrophication of surface waters. For better result of water quality we think it is necessary to use the third level of cleaning waste water (chemical treatment).
\end{abstract}

Keywords: WWTP, urban liquid discharges, BOD, SS, COD,

\section{Introduction}

\begin{abstract}
Natural water pollution by liquid waste is a critical fundamental problem in many countries. Liquid discharges may be sewage downloads, downloads rain water ("white water") and industrial liquid downloads. In many urban centers sewage is collected from rain waters and in some cases, industrial liquid wastes (processed or no treated)[1,2]. They are deposited in rivers, lakes and seas, often without any specific treatment, thus bec oming an important source of pollution. In some cases, they cause eutrophication of surface waters.

Wastewater discharges are the main source of pollution of natural waters, because they contain many substances that consume dissolved oxygen (causing a rapid decrease in the water content), soluble compounds of phosphorus and nitrogen (which can be cause eutrophication of water), bacteria and viruses pathogens, heavy metals such as $\mathrm{Cd}, \mathrm{Hg}, \mathrm{Zn}, \mathrm{Pb}, \mathrm{Cr}, \mathrm{Cu}$, and subject to spoil the look of the water and give them stink [3]. White waters when collected separately discharged into rivers, lakes or seas without any prior processing, although they carry dirt roads, including those of traffic. The content of pollutants in industrial liquid discharges may be very different, depending on the process technology and equipment for cleaning and recycling of water. Notice that, even slime and sludge arising from industrial facilities are considered as liquid waste [2,3].

Wastewater treatment is a necessity for the protection of natural waters from eutrophication. At the same time, increasing the concentration of population in urban centers and increasing population and demands for water industry, on the one hand, and reducing water and adequate reserves injury, on the other hand, has made water treatment black an acute problem in many advanced countries. It can be said that today many people use reuse water (i.e. previously used). It is estimated that $32 \%$ of the drinking water used in the United Kingdom, 50 to $70 \%$ of water supplied Paris with its suburbs, and $40 \%$ of the water used in Germany is reused water (after
\end{abstract}


treatment in liquid waste treatment plants). Of course, in these cases, it is necessary the wastewater to be treated in such a way that they become suitable for use and this it is made possible only by introducing three-tiered (stage) treatment [4,9].

\subsection{Urban liquid discharge characteristics}

Classes of sewage include sanitary, commercial, industrial, agricultural and surface runoff. The wastewater from residences and institutions, carrying body wastes, washing water, food preparation wastes, laundry wastes, and other waste products of normal living, are classed as domestic or sanitary sewage. Liquid-carried wastes from stores and service establishments serving the immediate community, termed commercial wastes, are included in the sanitary or domestic sewage category if their characteristics are similar to household flows. Wastes that result from an industrial process or the production or manufacture of goods are classed as industrial wastewater. Their flows and strengths are usually more varied, intense, and concentrated than those of sanitary sewage. Surface runoff, also known as storm flow or overland flow, is that portion of precipitation that runs rapidly over the ground surface to a defined channel. Precipitation absorbs gases and particulates from the atmosphere, dissolves and leaches materials from vegetation and soil, suspends matter from the land, washes spills and debris from urban streets and highways, and carries all these pollutants as wastes in its flow to a collection point [8,9].

\section{Physical characteristics}

Physical parameters that determine the quality of wastewater are: temperature, wind odor, color and turbidity, suspended solid waste (SS) and the change in the volume of wastewater. It may be noted that the maximum flow rate is between 07-15 hours during working hours[4].

\section{Chemical characteristics}

Chemical characteristics determine the chemical state of the waste and inorganic substances dissolved. They are based on 2 sets of labeled organic and inorganic. In wastewater nitrogen source for is urey $\mathrm{CO}(\mathrm{NH})_{2}$, which immediately divided into $\mathrm{CO}_{2}$ and $\mathrm{NH}_{3}$. After separation of proteins forme hydrogen sulphate. Carbohydrates contain carbon, hydrogen and oxygen, a typical example is the sugar and starch. These carbohydrate dissolve in organic acids by bacteria. Fats are composed of $76 \%$ carbon, $12 \%$ hydrogen and $12 \%$ oxygen and make the treatment process more difficult. Minced meat and skins come from two sources frome homes and industrial areas as well, and go straight to the membrane of the sewerage system and on the walls of the plant unit [4].

\section{Biological characteristics}

In wastewater are $10^{5}-10^{8}$ organisms / $\mathrm{ml}$. They live together in groups or separated and in general they are divided into two groups named as animal micro-organism. Ventilated bacteria living in sewage plant have a key role in the biological treatment process. They convert the dissolving organic substances in new cells and in inorganic substances. There is a large number of living organisms in sewage that can not be seen with the eye, but have an important role in cleaning wastewater [4].

\subsection{Sewage treatment}

Sewage treatment is the process of removing contaminants from wastewater and household sewage, both runoff (effluents) and domestic. It includes physical, chemical, and biological processes to remove physical, chemical and biological contaminants. Its objective is to produce an environmentally safe fluid waste stream (or treated effluent) and a solid waste (or treated sludge) suitable for disposal or reuse (usually as farm fertilizer). Using advanced technology it is now possible to re-use sewage effluent for drinking water, although Singapore is the only country to implement such technology on a production scale in its production of NEWater.

There are various schemes and designs of wastewater treatment, in which are combined physical, chemical and biological separation and destruction of pollutants. Wastewater treatment plants use three basic processes:

(a) The separation of solid particles or sludge containing pollutants;

(b) The elimination of polluting substances through accelerates destruction processes of biological and chemical treatments;

(c) Removing water from sewage sludge to reduce the volume to be deposited.

As for the methods of treatment they are classified in one stage method, two stages and three stage treatments $[5,9,10]$. 


\section{Waste Water Treatment Plant of Kavaja}

Increasing waste production by human activities enlarged the problem of how to get rid of these wastes without causing undesirable impact on the environment and humans. Sewage is a major carrier of dis ease (from human wastes) and toxins (from industrial wastes). The safe treatment of sewage is thus crucial to the health of any community. This article focuses on the complex physical and biological treatments used to render sewage both biologically and chemically harmless.

The Albanian Middle region has two sewage treatment plants: one in Qerret (Kavaja) and one in Durres. The process described below is that used by the Qerret (Kavaja) Waste Water Treatment Plant (WWTPK). The WWTPK is set up in 22.11.2005 and currently serves Kavaja city and the Synej village and it is designed for a capacity of 25000 people. It is the first such treatment plant build in Albania and its methods are similar to those used throughout the country $[6,7]$.

The waste treated is a mixture of domestic and industrial waste, with the domestic accounting for slightly more than half of the total. Some storm water also enters the system through leaks and illegal connections.

Sewage is a mixture of domestic and industrial wastes. It is more than $99 \%$ water, but the remainder contains some ions, suspended solids and harmful bacteria that must be removed before the water is released into the coastal sea.

\section{Volume and composition}

On average, $280000 \mathrm{~m}^{3}$ of sewage arrives each day, although during winter storms this can swell to $800000 \mathrm{~m}^{3}$. Of this, $99.9 \%$ is water. The remainder is mostly organic matter $\left(80-100 \mathrm{~g} \mathrm{~m}^{-3}\right)$ which constitutes the bulk of the suspended solids $\left(20-50 \mathrm{~g} \mathrm{~m}^{-3}\right)$. The biological processes which break down this organic matter require oxygen, and the amount of oxygen required is calculated as the wastewater's "biochemical oxygen demand" (BOD). Sewage coming into the plant (influent) has a BOD of between 100 and $200 \mathrm{~g} \mathrm{~m}^{-3}$ (i.e. 100 to 200 grams of oxygen are required to oxidize each cubic meter of influent). The remaining organic matter consists of the fat and grease that form a scum on the surface of the influent [5].

The influent generally contains no dissolved oxygen, so this must be added at various stages of the process to enable the organics to be broken down.

\subsection{Sewage Treatment process}

The purification works at Qerret (Kavaja) provide both primary and secondary treatment processes. Primary treatment removes most of the solids from the effluent, but doesn't remove or degrade the dissolved organic matter. Secondary treatment uses microorganisms to convert these organics to simple compounds. The effluent is then safe to be discharged into the coastal shore of the Adriatic Sea. The entire process is shown diagrammatically in Figure $1[5,7]$.

Conditions in the ponds promote the growth of unicellular algae: minute plants which, like any other plants, absorb carbon dioxide in daylight and give off oxygen by photosynthesis. This oxygen oxidizes the organics, thus purifying the sewage by reducing its oxygen demand.

\section{Pretreatment}

Large solids (i.e. those with a diameter of more than $2 \mathrm{~cm}$ ) and grit (heavy solids) are removed by screening. These are disposed of in landfills [5].

\section{Primary treatment}

The water is left to stand so that solids can sink to the bottom and oil and grease can rise to the surface. The solids are scraped off the bottom and the scum is washed off with water jets. These two substances are combined to form sludge [5].

Figure 1 : Sewage Treatment Flow Diagram

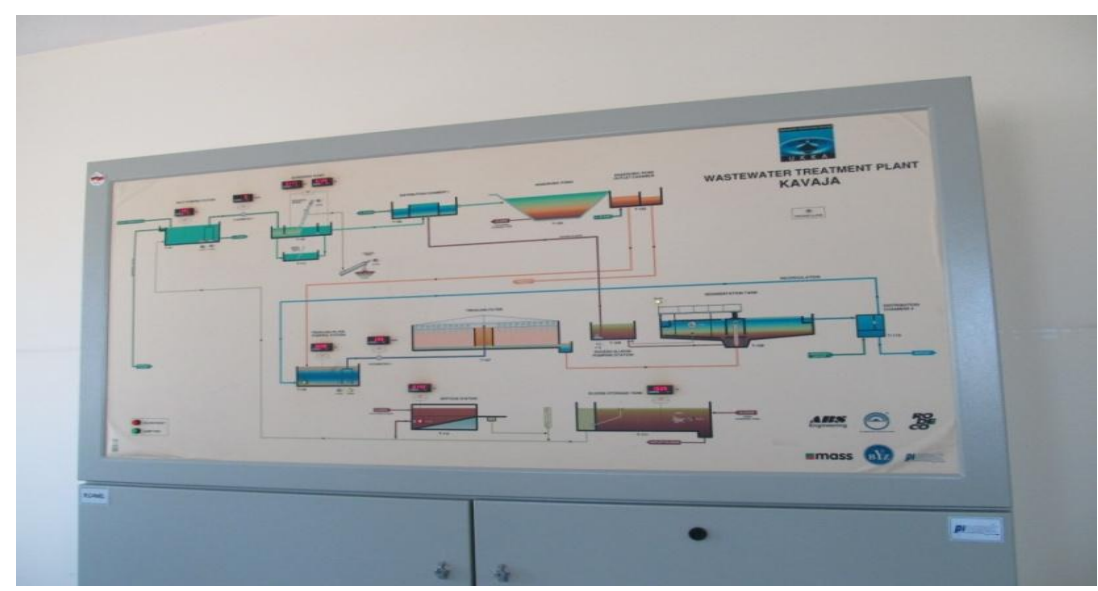




\section{Secondary treatment}

The sludge is further treated in 'sludge digesters': large heated tanks in which its chemical decomposition is catalyzed by microorganisms. The sludge is largely converted to 'biogas', a mixture of $\mathrm{CH}_{4}$ and $\mathrm{CO}_{2}$, which is used to generate electricity for the plant.

The liquid is treated by bacteria which break down the organic matter remaining in solution. It is then sent to oxidation ponds where heterotrophic bacteria continue the breakdown of the organics and solar UV light destroys the harmful bacteria [5].

\section{The role of the laboratory}

A wide variety of analytical tests are used to determine the purity of the was tewater at various stages of treatment so that the possibility of harm to either people or the environment is minimized [5].

In order to determine the productivity and to predict the future of the operation the results of the analysis of $\mathrm{BOD}, \mathrm{COD}, \mathrm{SS}, \mathrm{pH}$, temperature and dissolved oxygen are prepared by chemical laboratory equipment of WWTP.

BOD and COD analysis are prepared from samples of wastewater in the entrance of the plant, in the manholes of Lagoon and in the well or flask DISTRIBUCION 4. All analyzes performed in the laboratory room in the Administrative building of the WWTP and preservation of the results is passed out in the results table for the description in the future work.

The value of $\mathrm{pH}$, oxygen demand and temperature was taken from universal WTW meter in different parts of the plant, every day. It was noted that in the period from January to July 2012 this equipment was obsolete.

COD analysis is conducted using laboratory COD reaction coil, magnetic stirrer with heating, water distiller. As for BOD analyzes were conducted using BOD bottles.

\subsection{Assessment of water quality discharges from Waste Water Treatment Plants}

Some of the water quality standards used in our country is expressed by the MoE water quality standards of the Republic of Albania. In the table below (Table 1) are shown the quality standards of discharged water from the wastewater treatment plants [8].

Table 1 : Rates of liquid discharges from Waste Water Treatment Plants

\begin{tabular}{|r|l|c|}
\hline No & Parameters & Concentrations (limits) \\
\hline 1 & Biological Oxygen Demand (BOD) & $25 \mathrm{mg} / \mathrm{l} \mathrm{O}$ \\
\hline 2 & Chemical Oxygen Demand (COD) & $125 \mathrm{mg} / \mathrm{l} \mathrm{O}$ \\
\hline 3 & Solids in suspension (SS) & $35 \mathrm{mg} / \mathrm{l}$ \\
\hline 4 & Total phosphorus & $1 \mathrm{mg} / \mathrm{l}$ \\
\hline
\end{tabular}

\section{Results and Discussing}

Chemical analyzes for COD, BOD and SS parameters were carried out once a week according to the methods and apparatus described above.

The dynamics of average values of Q (influent), COD, BOD, SS in waters for the months: February, May and June 2012 are is shown below (Table 2). As shown in this table (Table 2) and from the graph (Figure 2) we notice that in the rainy period (February), the flow rate at the entrance of the plant is relatively higher than in periods without rainfall (June), which in our view affects on the chemical parameters values.

Table 2 : Results of chemical analyzes for months: February, May and June 2012

\begin{tabular}{|c|c|c|c|c|c|c|c|c|c|}
\hline \multirow[b]{2}{*}{ Date } & \multicolumn{4}{|c|}{ Plant influents } & \multicolumn{2}{|c|}{ Lagoon output } & \multicolumn{3}{|c|}{ Plant effluents } \\
\hline & $\begin{array}{c}\mathrm{Q} \\
(\mathrm{m} 3 / \mathrm{d}) \\
\end{array}$ & $\begin{array}{l}\mathrm{COD} \\
(\mathrm{mg} / \mathrm{l})\end{array}$ & $\begin{array}{l}\text { BOD } \\
(\mathrm{mg} / \mathrm{l})\end{array}$ & $\begin{array}{l}\mathrm{SS} \\
(\mathrm{mg} / \mathrm{l})\end{array}$ & $\begin{array}{l}\text { COD } \\
(\mathrm{mg} / \mathrm{l})\end{array}$ & $\begin{array}{l}\text { BOD } \\
(\mathrm{mg} / \mathrm{l})\end{array}$ & $\begin{array}{l}\text { COD } \\
(\mathrm{mg} / \mathrm{l})\end{array}$ & $\begin{array}{l}\text { BOD } \\
(\mathrm{mg} / \mathrm{l})\end{array}$ & $\begin{array}{l}\mathrm{SS} \\
(\mathrm{mg} / \mathrm{l})\end{array}$ \\
\hline Feb & 5800 & 330 & 200 & 30 & 200 & 80 & 60 & 21 & 5 \\
\hline May & 2200 & 240 & 110 & 25 & 150 & 90 & 45 & 18 & 5 \\
\hline June & 1890 & 300 & 150 & 50 & 140 & 100 & 60 & 22 & 20 \\
\hline
\end{tabular}


Figure 2: Average values of influents $Q\left(\mathrm{~m}^{3} / \mathrm{d}\right)$

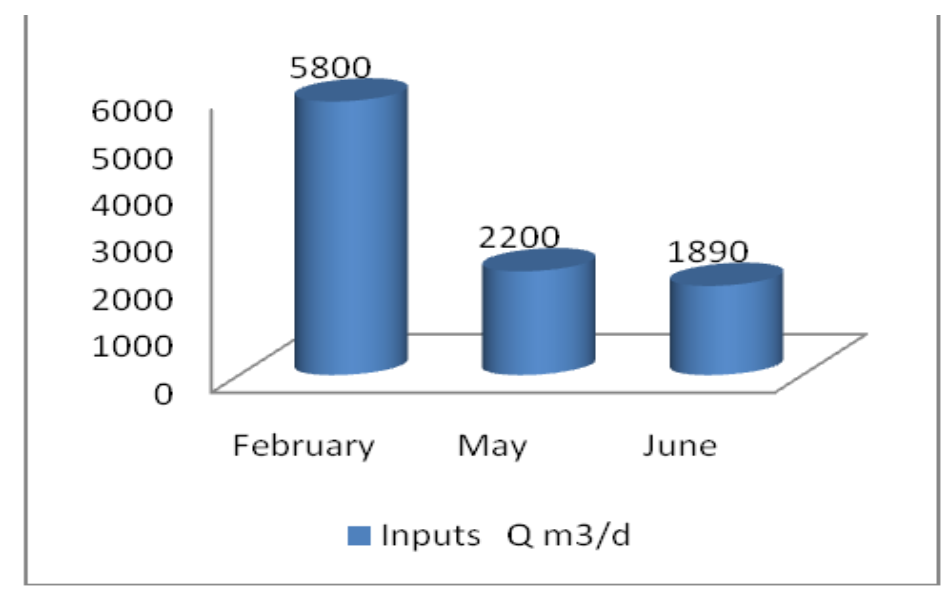

We must take in consideration that the higher values for the influents are: for COD in February, for BOD in February, while for solids in suspension (SS) the higher values are in May (Figure 3).

Figure 3 : Average values of COD, BOD, SS in influents

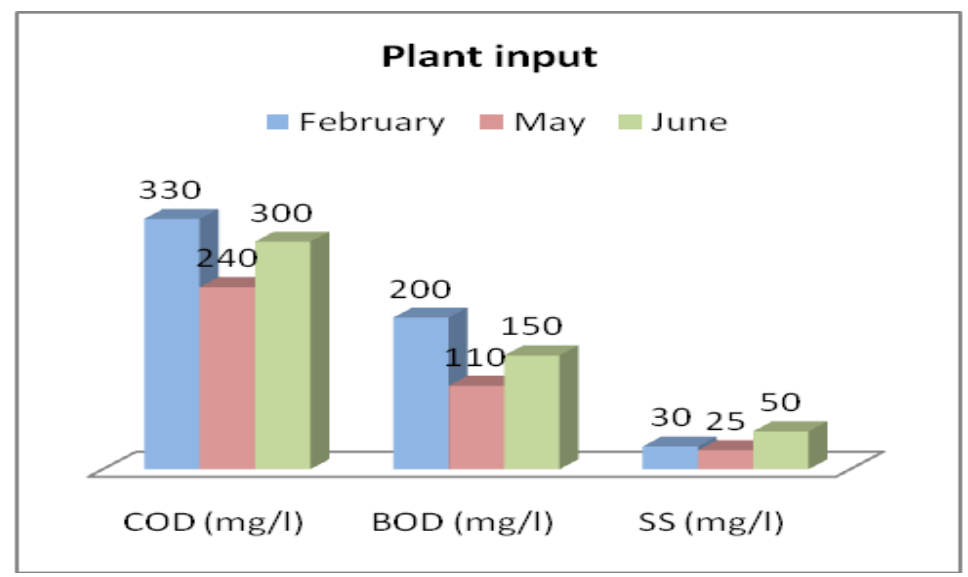

After the first stage- the pre-treating sewage, we observe low COD values (February $=4$ times less than input; May $=6$ times less and June $=6$ times less) and in terms of BOD values they are reduced in 6 times less (average) (February $=4$ times less; May $=8$ times less and in June $=7$ times less), comparing to the influen ts values.

The values of COD, BOD and SS are significantly reduced in the effluents (Figure 4, 5).

The assessment of comparing the values of chemical parameters between the influents and effluents of plant (before treatment and after treatment) are shown below (Figure 6, 7, 8).

There is a reduction of 5.5 times less of the values for the month of February, 5.3 times less for the month of May and 5 time less for the month of June for the COD. All the values of the effluents plant for the COD convene the rates permitted under MoE(Table 1.)

Figure 4 : Average values of parameters in the lagoon output 


\section{Lagoon output}

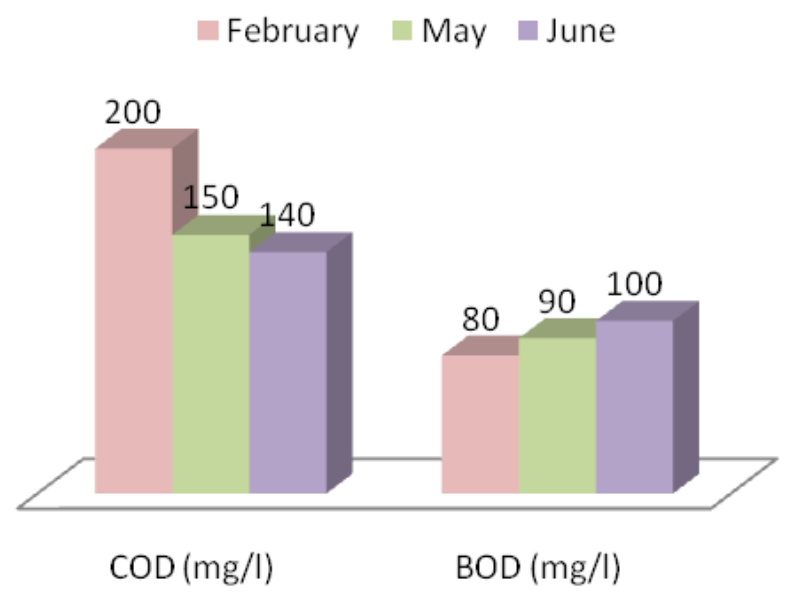

Figure 5 : Average values of parameters in the effluents (plant output)

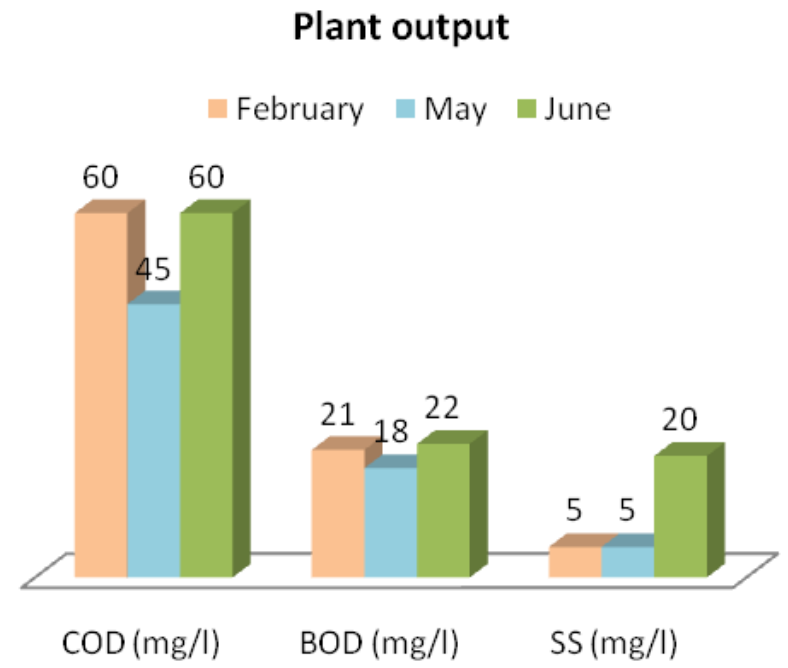

There is a reduction in value of 9.5 times less of the input values on February, 6.1 times less of the values on May, and 6.8 times less of the values on June for the $\mathrm{BOD}_{5}$. All the values of the effluents plant for the BOD convene the rates permitted under MoE(Table 1).

The values of solid suspensions (SS) range six times lower for the month of February, five times lower in May and 2.5 times lower for the month of June. Even these values of the effluents plant for the SS convene the rates permitted under MoE (Table 1.)

What is worth discussing is that in this facility is not performed total phosphorus chemical analysis. By knowing that the total phosphorus is the main parameter of nutrients to determine trophy status of surface waters, we think that is a necessity for performing this analysis in the plant before discharge to coas tal shore.

Figure 6 : Average values of COD before and after waste water treatment 


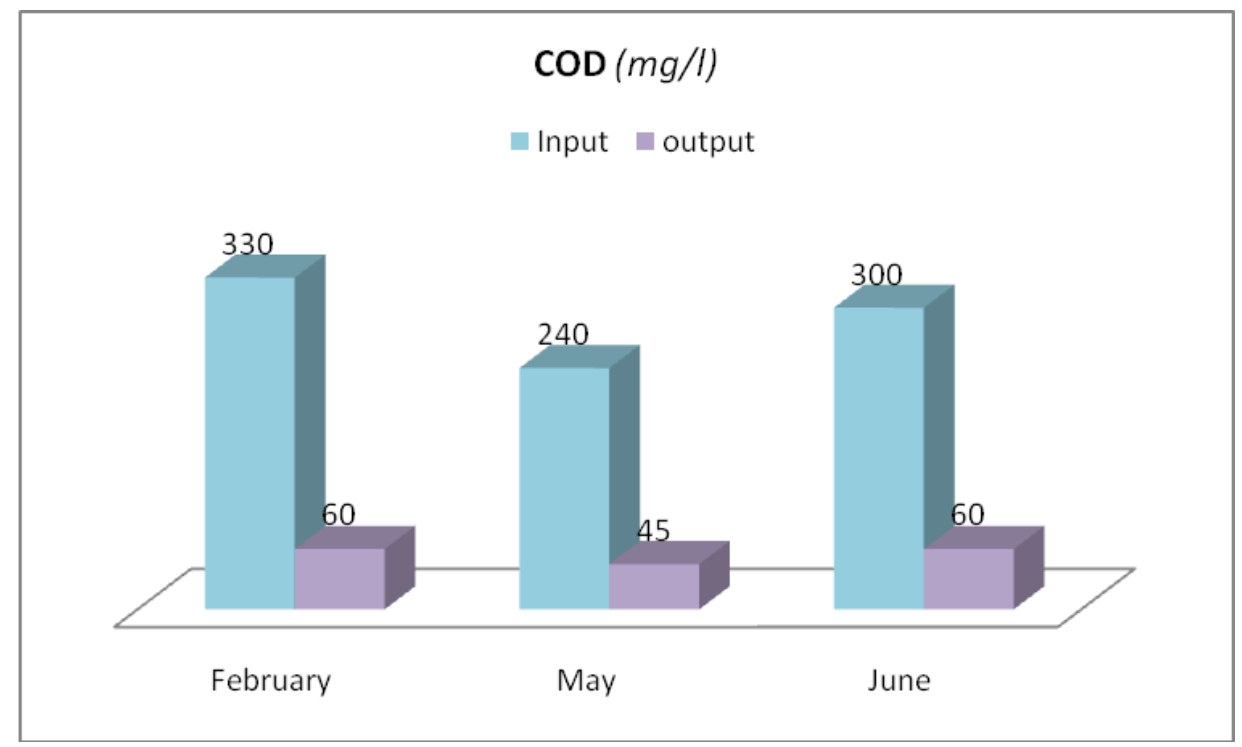

Figure 7 : Average values of BOD before and after waste water treatment

$$
\begin{aligned}
& \text { BOD }(m g / l) \\
& \text { Input } \square \text { Output }
\end{aligned}
$$

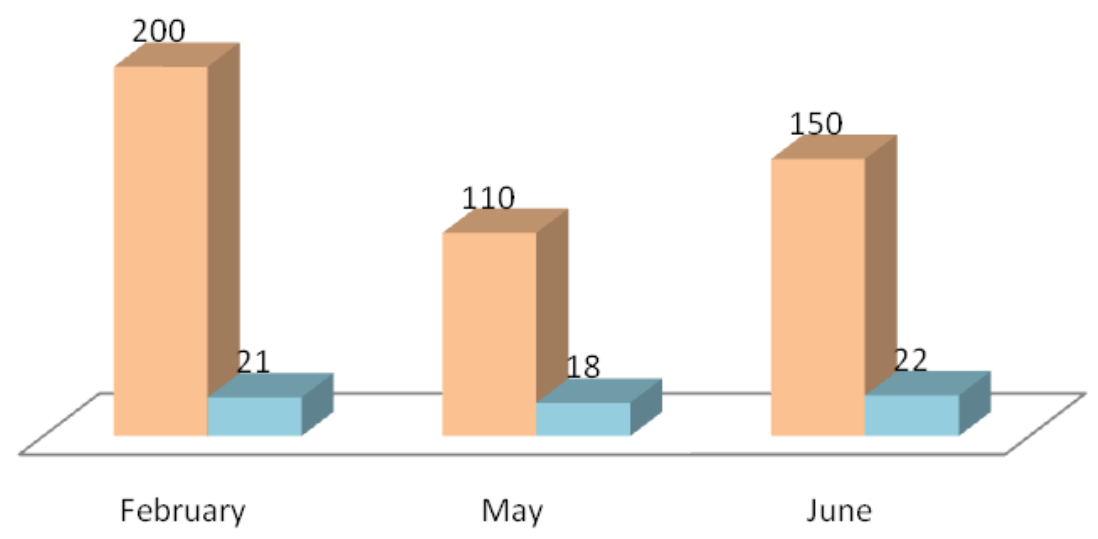

Figure 8: Average values of SS before and after waste water treatment 


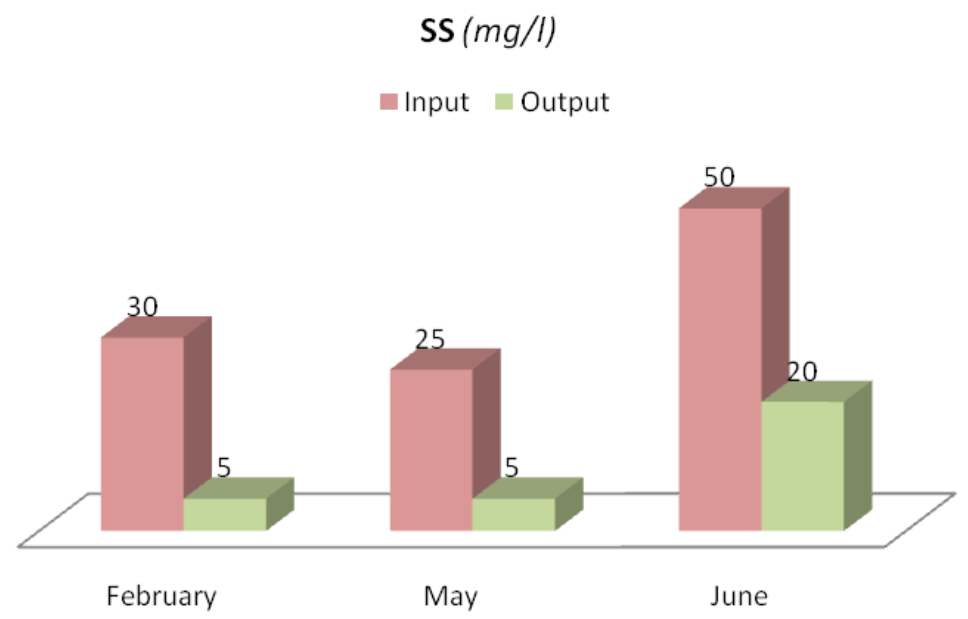

\section{Conclusion}

From this research we conclude that in the WWTP of Kavaja the wastewater treatment method used is that of the second stage method, physical and biological treatment; the WWTP of Kavaja is an important area sewage treatment and discharged untreated outdoor. As a work process deficiency of this plant we point: the lack of measurements of $\mathrm{pH}$, temperature and dissolved oxygen for a period of 1 year (from January 2011); lack of total phosphorus measurement procedure; lack of third stage of cleaning waste water (chemical treatment). According to the chemical analysis the water quality meets the standards of the Ministry of Environment for BOD, SS and COD parameters. From the treatment of sewage, except treated water, we obtain sludge waste in the form of humus, which later it will consider to be used in agriculture.

\section{References}

Bode A., Peza V., (2009) Post - transition environmental assessment in Albania. XIII BMPC Balkan Mineral Processing Congress- Bucharest-Romania-June 14-17, Proceeding, Volume II, pp 673.

Bode A., (2012) Impakti ambiental i ndotjeve antropogjene në pellgun ujëmbledhës të Tiranës. Tezë $P h D$, Biblioteka FGJM, Tiranë

Bode A., P. Zoga, (2009) Probleme të impaktit ambiental në grykëderdhjen e Semanit në detin Adriatik, Buletini Nafta Shqiptare, Vol 163, Nr3, pp 21

Cullaj A., (2010) Kimia e Mjedisit, ShblU, Tiranë, pp 45

Piomak Automationstechnik GmbH, (2005) Munich, Germany

INSTAT (2011); Republika e Shqipërisë

Komuna Golem, Kavajë. (2012)

Republika e Shqipërisë, MMPAU, (2009) Raport mbi gjendjen e mjedisit 2005-2007, Përmbledhje ekzekutive, Tiranë

S. Nixon, ed. CEarthTrends (2001), Quality and Quantity in Europe. Environmental Assessment Report No. 3. World Resources Institute

USEPA, (2004) Water Quality Criteria for Nitrogen and Phosphorus Pollution 